\title{
Red Alert: Labile Heme is an Alarmin
}

\author{
Miguel P. Soares* \& Marcelo T. Bozza**
}

\begin{abstract}
*Instituto Gulbenkian de Ciência, Rua da Quinta Grande, 6, 2780-156 Oeiras, Portugal, **Universidade Federal do Rio de Janeiro, Av. Carlos Chagas Filho 373, Cidade Universitária, 21941-902 Rio de Janeiro, Brazil. Correspondence to MPS (mpsosares@igc.gukbenkian.pt) or to MTB (mbozza@micro.ufrj.br)
\end{abstract}

\begin{abstract}
Alarmins are a heterogeneous group of endogenous molecules that signal cellular damage when sensed extracellularly. Heme is an endogenous molecule that acts as a prosthetic group of hemoproteins, such as hemoglobin and myoglobin. When released from damaged red blood cells or muscle cells, oxidized hemoglobin and myoglobin release their prosthetic heme groups, respectively. This generates labile heme, which is sensed by pattern recognition receptors (PRR) expressed by innate immune cells and possibly regulatory $T$ cells $\left(T_{R E G}\right)$. The ensuing adaptive response, which alerts for the occurrence of red blood cell or muscle cell damage, regulates the pathologic outcome of hemolysis or rhabdomyolysis, respectively. In conclusion, we propose that labile heme is an alarmin.
\end{abstract}

\section{Introduction}

This opinion article builds up on several assumptions. First, that all living organisms can sense events that alert for a possible disruption of homeostasis [1]. Second, that such sensors trigger adaptive responses that contribute to maintain or restore homeostasis $[2,3]$. Third, that host/microbe interactions often lead to disruption of homeostasis. Fourth, that sensing microorganisms alert for a possible disruption of homeostasis. Based on these general principles pattern recognition receptors (PRRs) where proposed to act as bona fide homeostatic sensors [1].

Engagement of PRR by pathogenic microorganisms is essential to elicit adaptive immune responses conferring resistance to infections [4,5]. In addition, PRR also play a pivotal role in maintaining steady state interactions with commensal microorganisms, as 
illustrated originally for host/microbiota interactions [6]. Moreover, PRR can sense endogenous molecules released from damaged cells [7], presumably reporting on cellular damage and on possible disruption of homeostasis. The endogenous molecules recognized by PRR were originally designated as danger associated molecular patters, based on the assumption that these are sensed when released from damaged cells $[8,9]$. The term alarmin is also used to refer to any endogenous molecule that signals cellular damage [10]. We shall argue herein that labile heme is a prototypical alarmin.

\section{Labile Heme}

Heme is an evolutionarily conserved molecular structure composed of a tetrapyrrole ring surrounding a single iron (Fe) atom (Figure 1). Heme acts essentially as a prosthetic group in a number of hemoproteins. These include hemoglobin $(\mathrm{Hb})$ and myoglobin $(\mathrm{Mb})$, which contain the largest pool of bioavailable heme in mammals [11]. When damaged, red blood cells and muscle cells release $\mathrm{Hb}$ and $\mathrm{Mb}$, respectively. Extracellular $\mathrm{Hb}$ and $\mathrm{Mb}$ are readily oxidized, via a process catalyzed by the transition of iron-heme from ferrous $\left(\mathrm{Fe}^{++}\right)$to ferric $\left(\mathrm{Fe}^{+++}\right)$state. This gives rise to methemoglobin [12-14] and metmyoglobin [15], respectively, which can release their prosthetic heme groups and generate labile heme, that is, redox active heme that is loosely bound to proteins or molecules, other than hemoproteins.

Under homeostatic conditions, extracellular $\mathrm{Hb}$ and labile heme are scavenged in plasma by haptoglobin and hemopexin, respectively $[16,17]$. Whether extracellular $\mathrm{Mb}$ is also scavenged in plasma is, to the best of our knowledge, not established. The resulting haptoglobin/Hb and hemopexin/heme complexes are captured by monocyte/macrophages (Mø) via the CD163 and CD91 receptors, respectively. This is associated with the induction of heme oxygenase-1 (HO-1) expression, a hemecatabolizing enzyme that generates carbon monoxide (CO), labile iron and biliverdin (reviewed in [11]). The end-products of heme catabolism can modulate Mø polarization, as demonstrated originally for $\mathrm{CO}$ [18]. Of note, when generated by Mø CO acts as a "microbial metabolic sensor" that fine-tunes Mø responses to live versus dead bacteria [19].

When the "scavenging capacity" of haptoglobin and hemopexin is exhausted, labile heme accumulates in plasma, where it becomes loosely bound to other plasma molecules that fail to restrain its redox activity. As such, labile heme becomes pro- 
oxidant and presumably therefore pathogenic. This pathogenic effect is perhaps best illustrated in the context of hemolytic conditions such as sickle cell disease, caused by mutations in the $\beta$ chain of $\mathrm{Hb}$ [20-22], malaria caused by Plasmodium infection [14,2325] or severe sepsis caused by systemic infections [26].

\section{Sensing labile heme}

The finding that when exposed in vitro to labile heme Mø secrete tumor necrosis factor (TNF) via a mechanism dependent on the expression of TLR4 and its adaptor signaling molecule MyD88, revealed that labile heme can be sensed by PRR [27]. More recently labile heme was shown to induce, again via a TLR4-dependent mechanism, the expression of molecules associated with endothelial cell activation, an effect that presumably contributes to the pathogenesis of sickle cell disease [20,22]. Labile heme acts irrespectively of the toll-Interleukin receptor (TIR) domain-containing adaptorinducing interferon- $\beta$ (IFN- $\beta$ )(TRIF) and fails to induce the expression of co-stimulatory molecules that support dendritic cell immunogenicity. This suggests that in contrast to other alarmins, labile heme has little or no "adjuvant" activity.

Murine Mø also secrete interleukin $1 \beta$ (IL-1 $\beta$ ) when exposed in vitro to labile heme [28]. This occurs via a mechanism dependent on the expression of the NOD-like receptor 3 (NLRP3) inflammasome, a cytosolic complex that includes the adaptor protein apoptosis-associated speck-like protein (ASC) and caspase-1, which processes pro-IL$1 \beta$ into IL-1 $\beta$ [28]. Activation of the NLRP3 inflammasome in response to heme occurs through a mechanism dependent on the phosphorylation of the spleen tyrosine kinase (Syk) as well as the production of reactive oxygen species (ROS) and cellular $\mathrm{K}^{+}$efflux, while acting independently of lysozomal damage or cathepsin activity [28]. These findings add labile heme to a number of structurally unrelated endogenous molecules sensed by the NLRP3 inflammasome. The observation that mice in which the NIrp3, Asc, caspase $1 / 11$ or $/ / 1 r$ alleles are deleted are more resilient to hemolysis [28], suggests that unfettered NLRP3 inflammasome activation and IL-1 $\beta$ secretion in response to labile heme drives inflammation and tissue damage associated with hemolysis. 


\section{Labile heme is an Alarmin}

Given the extraordinarily high intracellular heme content of red blood cells and muscle cells, as compared to any other cell type, sensing extracellular labile heme probably signals red blood cell and/or muscle cell damage, associated with hemolysis or rhabdomyolysis, respectively (Figure 2). In keeping with this notion, labile heme triggers cell autonomous and systemic adaptive responses that mitigate the pathogenic outcomes of hemolysis [25,29] and rhabdomyolysis [30]. This protective effect is mediated via a mechanism involving the expression of $\mathrm{HO}-1$ [13,14]. A similar adaptive response, involving the expression of $\mathrm{HO}-1$, contributes to the protective effect of sickle cell $\mathrm{Hb}$ against malaria [24,31]. Whether this involves heme sensing by PRR is likely, but remains to be established.

Alarmins can promote tissue damage repair, as illustrated in the context of muscle [32], intestinal [33] and lung [34] injury. The mechanisms via which this occurs are unclear but have been shown to involve the recruitment of tissue resident $T_{\text {REG }}$ that can sense alarmins. Upon migration, tissue resident $T_{\text {REG }}$ preserve the functional integrity of damaged tissues [32-34] via a mechanism involving the expression of molecules that act directly on parenchyma cells [34] and/or that polarize tissue-resident Mø towards tissue repair [32]. Whether labile heme, when released from damaged cells, acts in a similar manner is likely, but this has not been reported. In support of this notion, $T_{R E G}$ express TLR4 [35] and as such may sense labile heme. Moreover, induction of HO-1 in $\mathrm{T}_{\text {REG }}$ has been associated with enhanced $T_{\mathrm{REG}}$ function, which may contribute to tissue repair in a range of immune mediated inflammatory conditions where $\mathrm{HO}-1$ is protective $[13,36,37]$.

\section{Labile heme as an amplifier of inflammation}

Systemic infections are often associated with varying levels of hemolysis and in some cases with rhabdomyolysis as well. The extracellular $\mathrm{Hb}$ generated through hemolysis exerts anti-microbial effects, via the peroxidase activity of its prosthetic heme $b$ groups, which uses hydrogen peroxide $\left(\mathrm{H}_{2} \mathrm{O}_{2}\right)$ to oxidize molecules in microbes [38,39]. Moreover, binding of extracellular $\mathrm{Hb}$ to bacterial lipopolysaccharide (LPS) [40], alters the tertiary structure of $\mathrm{Hb}[39,41]$, enhancing its peroxidase and hence microbicidal activity [38,39]. Extracellular $\mathrm{Hb}$ enhances the pro-inflammatory activity of LPS [41] and when overtly oxidized can form large aggregates that act per se as a pro-inflammatory 
agonist in endothelial cells [42]. This suggests that extracellular $\mathrm{Hb}$ acts as a soluble PRR and a cytotoxic molecule promoting resistance to systemic infections [40].

When released from oxidized $\mathrm{Hb}$ and probably from other hemoproteins as well, labile heme can exert cytotoxic effects on pathogens, as illustrated for bacteria [43] and protozoan parasites [44]. Labile heme also synergizes with LPS to induce cytokine production in Mø [45], suggesting that under suboptimal microbial sensing via PRR [45], labile heme provides an amplification system that boosts inflammation. Presumably this enhances resistance to infection, a feature shared with other alarmins.

\section{Labile heme as a cytotoxic agonist}

Labile heme is not only a cytotoxic to pathogens but also to host cells $[44,46,47]$. The very same structural features that render heme $b$ a versatile redox active molecule when contained in the heme pockets of hemoproteins, drive its pathologic effects when released from those hemoproteins. The general principle being that the amphipathic nature of the tetrapyrrole ring of heme favors its interaction with nonpolar molecules such as phospholipids in cellular membranes. If not countered promptly, via heme cellular export [48] or catabolism [13,14], labile heme catalyzes lipid peroxidation, leading to programmed cell death $[12-14,23,26,47]$. Presumably this cytotoxic effect contributes critically to tissue damage associated with the pathogenesis of sickle cell disease [20-22], malaria [14,23-25] and severe sepsis [26].

Labile heme interacts synergistically with pro-inflammatory cytokines such as TNF [23] as well as other agonists such as Fas, ROS and reactive nitrogen species (RNS) $[13,26]$ to induce programmed cell death in a variety of parenchyma cells $[13,14,23,26,47,49,50]$. Briefly, labile heme sensitizes parenchyma cells to undergo TNF-mediated programmed cell death via a mechanism that involves the iron contained in its tetrapyrrole ring, which reacts with hydrogen peroxide $\left(\mathrm{H}_{2} \mathrm{O}_{2}\right)$ and catalyzes, via the Fenton chemistry, the production of hydroxyl radicals $(\mathrm{OH})$ [13,51]. Sustained ROS production overrides the cytoprotective program triggered via activation of the nuclear factor kappa B (NF-kB) family of transcription factors [52] and sustains the activation of the c-Jun N-terminal Kinase (JNK) leading to programmed cell death [49][53,54]. Presumably, this occurs via inhibition of redox-sensitive phosphatases that control JNK activation in response to TNF [55,56]. In keeping with this notion, antioxidants such as 
the glutathione precursor $\mathrm{N}$-acetyl cysteine suppress heme-driven JNK activation and the cytotoxic effect of labile heme and TNF $[13,14,23,26,49,57]$. Moreover, intracellular sequestration of labile iron by ferritin acts as an endogenous anti-oxidant that prevents sustained JNK activation and programmed cell death in response to heme and TNF [52]. This suggests that in parenchyma cells the pro-oxidant effect of labile heme is mediated, at least in part by iron, when released from the protoporphyrin ring of heme [13,23].

The effector mechanisms underlying the cytotoxic effect of labile heme in parenchyma are likely cell-type specific. Based on morphological and biochemical characteristics, including caspase-3 activation, membrane blebbing, nuclear shrinking/fragmentation, chromatin condensation and formation of apoptotic bodies, labile heme appears to sensitize hepatocytes to undergo apoptosis in response to TNF [23].

Mø also undergo programmed cell death when exposed to labile heme [58]. However, labile heme induces Mø to undergo necroptosis, rather than apoptosis. This occurs through a mechanism involving TLR4-driven NF-kB activation, the production of TNF and TNF receptor 1 (TNFR1) signaling. Sustained ROS production drives JNK and receptor-interacting serine/threonine-protein kinase (RIPK) 1 and RIPK3 activation, leading to necroptosis [58]. The pro-oxidant effect of labile heme in Mø occurs independently of TLR4 [27] but involves the expression of NADPH oxidase-2 (NOX2)/gp91 ${ }^{\text {phox }}[59-61]$ and the mitochondrial electron transport chain $[28,62]$. Whether ROS production also involves a receptor-mediated process that senses labile heme is not clear. A similar signal transduction pathway, leading to programmed cell death, applies to microglia [63] and to astrocytes [64].

The mechanism via which labile heme triggers programmed cell death in Mø contrasts to some extent with the one operating in parenchyma cells, which fail to produce TNF in response to labile heme. As such labile heme per se does not trigger programmed cell death in parenchyma cells. Heme becomes cytotoxic to parenchyma cells, only in the presence of exogenous TNF, ROS or RNS produced by bystander cells such as activated Mø. 


\section{Conclusion}

Labile heme is a prototypical alarmin. In contrast to other alarmins however, labile heme is endowed with cytotoxicity, potentially amplifying the release of other alarmins from damaged cells. Presumably this explains the broad protective effects exerted by the adaptive response triggered in response to this alarmin, which converges at the level of heme catabolism by $\mathrm{HO}-1$ and act in a protective manner against a variety of immune mediated inflammatory diseases.

\section{Acknowledgements}

The authors thank Luis Ferreira Moita (Instituto Gulbenkian de Ciência) for critical review of the manuscript and Zélia Gouveia for producing the heme structures in Figure 1. MPS is supported by Fundação Calouste Gulbenkian and by grants from the Fundação para a Ciência e Tecnologia (PTDC/SAU TOX/116627/2010, HMSP-ICT/0022/2010) and by the European Community 7th Framework Grant ERC-2011-AdG. 294709-DAMAGECONTROL. MTB is supported by Fundação de Amparo a Pesquisa do Estado do Rio de Janeiro (FAPERJ), Conselho Nacional de Pesquisa (CNPq), fINCTDengue, and Coordenacao de Aperfeicoamento de Pessoal de Nivel Superior (CAPES), Brazil.

Note: While preparing this manuscript another manuscript putting forward similar notions was published elsewhere: "Heme as a danger molecule in pathogen recognition" By Barbara Wegiel, Carl J. Hauser, Leo E. Otterbein, Free Radical Biology and Medicine. Volume 89, Received 13 July 2015, Accepted 8 August 2015, Available online 9 October 2015 


\section{BOX1: Heme as a TLR4 agonist:}

When assigning an endogenous molecule as a putative TLR4-ligand one should consider the possibility that this molecule may be contaminated by LPS (i.e. endotoxin), a promiscuous TLR4-ligand present in many commercially available reagents. In the case of labile heme this possibility was excluded by a series of independent observations; i) LPS, e.g. lipid A, antagonists fail to inhibit the proinflammatory activity of labile heme and antibodies that block the binding of LPS to TLR4 and/or to MD-2 fail to inhibit the pro-inflammatory activity of labile heme [27]; ii) Protoporphyrin IX, a tetrapyrrole ring identical to heme but lacking the iron molecule, acts as competitive inhibitor of labile heme while not interfering with the activity of LPS [27], iii) Serum blocks the pro-inflammatory activity of labile-heme while supporting that of LPS [27]; iv) The pro-inflammatory activity of labile heme acts irrespectively of the Toll-Interleukin receptor (TIR) domain-containing adaptor-inducing interferon- $\beta$ (IFN $\beta$ ) (TRIF) or MD-2 [27,58]. This argues that labile heme is an endogenous TLR4 ligand that binds to TLR4 in a distinct manner from LPS [65].

\section{Figure legends}

Figure 1: Specific alterations in the vinyl and methyl groups of the tetrapyrrole ring of heme define heme $a\left(\mathrm{C}_{49} \mathrm{H}_{56} \mathrm{O}_{6} \mathrm{~N}_{4} \mathrm{Fe}\right), b\left(\mathrm{C}_{34} \mathrm{H}_{32} \mathrm{O}_{4} \mathrm{~N}_{4} \mathrm{Fe}\right)$ and $c\left(\mathrm{C}_{34} \mathrm{H}_{36} \mathrm{O}_{4} \mathrm{~N}_{4} \mathrm{~S}_{2} \mathrm{Fe}\right)$. Heme $a$ associates, via hydrogen bonds formed by the formyl and hydroxyfarnesylethyl groups of the tetrapyrrole ring, with arginines and serines in hemoproteins such as cytochrome $c$ oxidase. Heme $c$ is less abundant and binds covalently, through the tetrapyrrole vinyl groups, to cysteines in hemoproteins such as cytochrome c. Heme $b$, the most abundant form of heme, associates via van der Waals contacts and salt-bridges in the propionate group of the tetrapyrrole ring, to hydrophobic amino acids in hemoproteins, such as hemoglobin $(\mathrm{Hb})$ and myoglobin $(\mathrm{Mb})$.

Figure 2: Labile heme acts as a bona fide inflammatory agonist, inducing the activation and migration of polymorphonuclear (PMN) cells $[59,60,66]$ as well as the activation of Mø [59,61,62,67-69] and endothelial cells [20]. In some cases this is mediated via a mechanism involving heme sensing by PRR $[20,27,28]$ as well as $\mathrm{G}$ coupled proteins 
(GCP) in PMN cells [59]. This argues that extracellular labile heme acts as an alarmin, that is, an endogenous molecule that when sensed in the extracellular space signals cellular damage [10].

\section{References}

1. Kotas ME, Medzhitov R: Homeostasis, Inflammation, and Disease Susceptibility. Cell 2015, 160:816-827. **

**This article provides a conceptual framework on the overall principles at play at the interface of homeostasis, inflammtion and immunity.

2. Soares MP, Gozzelino R, Weis S: Tissue damage control in disease tolerance. Trends Immunol 2014, 35:483-494.*

3. Chovatiya R, Medzhitov R: Stress, inflammation, and defense of homeostasis. Mol Cell 2014, 54:281-288.*

${ }^{*}$ References 2 and 3 propose a series of mechanisms regulating adaptive reponses to different forms of stress and damage associated with inflammation and immunity. The uderlying notion being that these adaptive responses disentangle inflammation and immunity from tissue damage and disease.

4. Janeway CA, Jr.: Approaching the asymptote? Evolution and revolution in immunology. Cold Spring Harb Symp Quant Biol 1989, 54 Pt 1:1-13.

5. Medzhitov R, Preston-Hurlburt P, Janeway CA, Jr.: A human homologue of the Drosophila Toll protein signals activation of adaptive immunity. Nature 1997, 388:394-397.

6. Rakoff-Nahoum S, Paglino J, Eslami-Varzaneh F, Edberg S, Medzhitov R: Recognition of commensal microflora by toll-like receptors is required for intestinal homeostasis. Cell 2004, 118:229-241.

7. Medzhitov R: Origin and physiological roles of inflammation. Nature 2008, 454:428-435.

8. Seong S-Y, Matzinger P: Hydrophobicity: an ancient damage-associated molecular pattern that initiates innate immune responses. Nat Rev Immunol 2004, 4 469-478.

9. Matzinger P: Tolerance, danger, and the extended family. Annual Review of Immunology 1994, 12:991-1045.

10. Bianchi ME: DAMPs, PAMPs and alarmins: all we need to know about danger. $J$ Leukoc Biol 2007, 81:1-5.

11. Soares MP, Weiss G: The Iron age of host-microbe interactions. EMBO reports 2015.

12. Balla J, Jacob HS, Balla G, Nath K, Eaton JW, Vercellotti GM: Endothelial-cell heme uptake from heme proteins: induction of sensitization and desensitization to oxidant damage. Proceedings of the National Academy of Sciences of the United States of America 1993, 90:9285-9289.

13. Gozzelino R, Jeney V, Soares MP: Mechanisms of cell protection by heme oxygenase-1. Annu Rev Pharmacol Toxicol 2010, 50:323-354.

14. Gozzelino R, Soares MP: Coupling heme and iron metabolism via ferritin H chain. Antioxid Redox Signal 2014, 20:1754-1769.

15. George P, Stratmann CJ: The oxidation of myoglobin to metmyoglobin by oxygen. I. Biochem J 1952, 51:103-108. 
16. Ascenzi P, Bocedi A, Visca P, Altruda F, Tolosano E, Beringhelli T, Fasano M: Hemoglobin and heme scavenging. IUBMB Life 2005, 57:749-759.

17. Schaer DJ, Buehler PW, Alayash Al, Belcher JD, Vercellotti GM: Hemolysis and free hemoglobin revisited: exploring hemoglobin and hemin scavengers as a novel class of therapeutic proteins. Blood 2013, 121:1276-1284.

18. Otterbein LE, Bach FH, Alam J, Soares MP, Tao HL, Wysk M, Davis R, Flavell R, Choi AMK: Carbon monoxide mediates anti-inflammatory effects via the mitogen activated protein kinase pathway. Nature Medicine 2000, 6:422-428.

19. Wegiel B, Larsen R, Gallo D, Chin BY, Harris C, Mannam P, Kaczmarek E, Lee PJ, Zuckerbraun BS, Flavell R, et al.: Macrophages sense and kill bacteria through carbon monoxide-dependent inflammasome activation. J Clin Invest 2014, 124:4926-4940.**

${ }^{* *}$ Carbon monoxide acts as a microbial metabolic sensor when generated through heme catabolism by heme oxygenase-1 in macrophages. CO binds to microbial heme-containing respiratory complexes and induces the production of ATP in live but not in dead bacteria, leading to inflammasome activation and ultimately to bacterial clearance by macrophages. This suggests that carbon monoxide provides macrophages with the means to fine tune reponses to live versus dead bacteria.

20. Belcher JD, Chen C, Nguyen J, Milbauer L, Abdulla F, Alayash AI, Smith A, Nath KA, Hebbel RP, Vercellotti GM: Heme triggers TLR4 signaling leading to endothelial cell activation and vaso-occlusion in murine sickle cell disease. Blood 2014, 123:377-390.

21. Vinchi F, Gastaldi S, Silengo L, Altruda F, Tolosano E: Hemopexin prevents endothelial damage and liver congestion in a mouse model of heme overload. Am J Pathol 2008, 173:289-299.

22. Ghosh S, Adisa OA, Chappa P, Tan F, Jackson KA, Archer DR, Ofori-Acquah SF: Extracellular hemin crisis triggers acute chest syndrome in sickle mice. J Clin Invest 2013, 123:4809-4820.

${ }^{*}$ Based on the original findings described under reference 27 , the articles referenced as 20-22 extend the notion that labile heme is sensed by TLR4 in vascular endothelial cells. Moreover, these articles explore the impact of labile heme recognition by TLR4 on the pathogenesis of sickle cell disease.

23. Seixas E, Gozzelino R, Chora A, Ferreira A, Silva G, Larsen R, Rebelo S, Penido C, Smith NR, Coutinho A, et al.: Heme oxygenase-1 affords protection against noncerebral forms of severe malaria. Proc Natl Acad Sci U S A 2009, 106:1583715842.

24. Ferreira A, Balla J, Jeney V, Balla G, Soares MP: A central role for free heme in the pathogenesis of severe malaria: the missing link? $J \mathrm{Mol}$ Med 2008, 86:1097-1111.

25. Pamplona A, Ferreira A, Balla J, Jeney V, Balla G, Epiphanio S, Chora A, Rodrigues $C D$, Gregoire IP, Cunha-Rodrigues $M$, et al.: Heme oxygenase-1 and carbon monoxide suppress the pathogenesis of experimental cerebral malaria. Nat Med 2007, 13:703-710.

26. Larsen R, Gozzelino R, Jeney V, Tokaji L, Bozza FA, Japiassu AM, Bonaparte D, Cavalcante MM, Chora A, Ferreira A, et al.: A central role for free heme in the pathogenesis of severe sepsis. Sci Transl Med 2010, 2:51ra71.

27. Figueiredo RT, Fernandez PL, Mourao-Sa DS, Porto BN, Dutra FF, Alves LS, Oliveira MF, Oliveira PL, Graca-Souza AV, Bozza MT: Characterization of heme as activator of Toll-like receptor 4. J Biol Chem 2007, 282:20221-20229. 
28. Dutra FF, Alves LS, Rodrigues D, Fernandez PL, de Oliveira RB, Golenbock DT, Zamboni DS, Bozza MT: Hemolysis-induced lethality involves inflammasome activation by heme. Proc Natl Acad Sci U S A 2014. **

${ }^{* *}$ Original demonstration that labile heme is sensed by the NLRP3 inflammasome. The article also demonstrstes the impact of heme-driven inflammasome activation on the patgenesis of hemolytic conditions.

29. Belcher JD, Mahaseth H, Welch TE, Otterbein LE, Hebbel RP, Vercellotti GM: Heme oxygenase-1 is a modulator of inflammation and vaso-occlusion in transgenic sickle mice. J Clin Invest 2006, 116:808-816.

30. Nath KA, Balla G, Vercellotti GM, Balla J, Jacob HS, Levitt MD, Rosenberg ME: Induction of heme oxygenase is a rapid, protective response in rhabdomyolysis in the rat. Journal of Clinical Investigation 1992, 90:267-270.

31. Ferreira A, Marguti I, Bechmann I, Jeney V, Chora A, Palha NR, Rebelo S, Henri A, Beuzard Y, Soares MP: Sickle Hemoglobin Confers Tolerance to Plasmodium Infection. Cell 2011, 145: 398-409.

32. Burzyn D, Kuswanto W, Kolodin D, Shadrach JL, Cerletti M, Jang Y, Sefik E, Tan TG, Wagers AJ, Benoist C, et al.: A special population of regulatory $\mathbf{T}$ cells potentiates muscle repair. Cell 2013, 155:1282-1295.

33. Schiering C, Krausgruber T, Chomka A, Frohlich A, Adelmann K, Wohlfert EA, Pott J, Griseri T, Bollrath J, Hegazy AN, et al.: The alarmin IL-33 promotes regulatory T-cell function in the intestine. Nature 2014, 513:564-568.

34. Arpaia N, Green JA, Moltedo B, Arvey A, Hemmers S, Yuan S, Treuting PM, Rudensky AY: A Distinct Function of Regulatory T Cells in Tissue Protection. Cell 2015, 162:1078-1089. **

${ }^{* *}$ References 32-34 demonstrate that tissue resident regulatory $T$ cells contribute critically to tissue repair. The mechanism via which this occurs involves sensing of alarmins released from damaged cells. This triggers tissue resident regulatory $T$ cells to promote tissue repair via a mechanism involving the expression of specicifc genes, e.g. amphiregulin (reference 43) acting on Mø and/or parenchyma tissues.

35. Caramalho I, Lopes-Carvalho T, Ostler D, Zelenay S, Haury M, Demengeot J: Regulatory $T$ cells selectively express toll-like receptors and are activated by lipopolysaccharide. J Exp Med 2003, 197:403-411.

36. Soares MP, Marguti I, Cunha A, Larsen R: Immunoregulatory effects of HO-1: how does it work? Curr Opin Pharmacol 2009, 9:482-489.

37. Soares MP, Bach FH: Heme oxygenase-1: from biology to therapeutic potential. Trends Mol Med 2009, 15:50-58.

38. Jiang N, Tan NS, Ho B, Ding JL: Respiratory protein-generated reactive oxygen species as an antimicrobial strategy. Nat Immunol 2007, 8:1114-1122.

39. Du R, Ho B, Ding JL: Rapid reprogramming of haemoglobin structure-function exposes multiple dual-antimicrobial potencies. EMBO J 2010, 29:632-642.

40. Lee SK, Ding JL: A perspective on the role of extracellular hemoglobin on the innate immune system. DNA Cell Biol 2013, 32:36-40.

41. Kaca W, Roth RI, Levin J: Hemoglobin, a newly recognized lipopolysaccharide (LPS)-binding protein that enhances LPS biological activity. J Biol Chem 1994, 269:25078-25084.

42. Silva G, Jeney V, Chora A, Larsen R, Balla J, Soares MP: Oxidized hemoglobin is an endogenous proinflammatory agonist that targets vascular endothelial cells. J Biol Chem 2009.

43. Anzaldi LL, Skaar EP: Overcoming the heme paradox: heme toxicity and tolerance in bacterial pathogens. Infect Immun 2010, 78:4977-4989. 
44. Orjih AU, Banyal HS, Chevli R, Fitch CD: Hemin lyses malaria parasites. Science 1981, 214:667-669.

45. Fernandez AZ, Lopez F, Tablante A, Romano E, Hurt-Camejo E, Camejo G, ApitzCastro R: Intravascular hemolysis increases atherogenicity of diet-induced hypercholesterolemia in rabbits in spite of heme oxygenase-1 gene and protein induction. Atherosclerosis 2001, 158:103-111.

46. Vile GF, Basumodak S, Waltner C, Tyrrell RM: Heme oxygenase mediates an adaptive response to oxidative stress in human skin fibroblasts. Proceedings of the National Academy of Sciences of the United States of America 1994, 91:2607-2610.

47. Balla G, Jacob HS, Balla J, Rosenberg M, Nath K, Apple F, Eaton JW, Vercellotti GM: Ferritin: a cytoprotective antioxidant strategem of endothelium. Journal of Biological Chemistry 1992, 267:18148-18153.

48. Korolnek T, Hamza I: Macrophages and iron trafficking at the birth and death of red cells. Blood 2015, 125:2893-2897.

49. Gozzelino R, Andrade BB, Larsen R, Luz NF, Vanoaica L, Seixas E, Coutinho A, Cardoso S, Rebelo S, Poli M, et al.: Metabolic adaptation to tissue iron overload confers tolerance to malaria. Cell Host Microbe 2012, 12:693-704. ${ }^{* *}$ Demonstration that stress responsive genes that counter the cytotoxic effects of labile heme, such as the ferritin $H$ chain, play a central role in limiting the extent of tissue damage associated with systemic infections. These genes are said to provide tissue damage control and to confer disease tolerance to infection, an evolutionary conserved defence strategy against infection that limits disease severity without interfering with the host's pathogen load.

50. Sukumari-Ramesh S, Laird MD, Singh N, Vender JR, Alleyne CH, Jr., Dhandapani $\mathrm{KM}$ : Astrocyte-derived glutathione attenuates hemin-induced apoptosis in cerebral microvascular cells. Glia 2010, 58:1858-1870.

51. Fenton $\mathrm{HJH}$ : Oxidation of tartaric acid in presence of iron. Journal of the Chemical society (Lond.) 1894, 65:899-910.

52. Beg AA, Baltimore D: An essential role for NF-kappaB in preventing TNF-alphainduced cell death. Science 1996, 274:782-784.

53. Tang G, Minemoto Y, Dibling B, Purcell NH, Li Z, Karin M, Lin A: Inhibition of JNK activation through NF-kappaB target genes. Nature 2001, 414:313-317.

54. Bubici C, Papa S, Pham CG, Zazzeroni F, Franzoso G: The NF-kappaB-mediated control of ROS and JNK signaling. Histol Histopathol 2006, 21:69-80.

55. Pham CG, Bubici C, Zazzeroni F, Papa S, Jones J, Alvarez K, Jayawardena S, De Smaele $E$, Cong R, Beaumont $C$, et al.: Ferritin heavy chain upregulation by NFkappaB inhibits TNFalpha-induced apoptosis by suppressing reactive oxygen species. Cell 2004, 119:529-542.

56. Kamata H, Honda S, Maeda S, Chang L, Hirata H, Karin M: Reactive oxygen species promote TNFalpha-induced death and sustained JNK activation by inhibiting MAP kinase phosphatases. Cell 2005, 120:649-661.

57. Larsen R, Gouveia Z, Soares MP, Gozzelino R: Heme cytotoxicity and the pathogenesis of immune-mediated inflammatory diseases. Front Pharmacol 2012, 3:77.

58. Fortes GB, Alves LS, de Oliveira R, Dutra FF, Rodrigues D, Fernandez PL, SoutoPadron T, De Rosa MJ, Kelliher M, Golenbock D, et al.: Heme induces programmed necrosis on macrophages through autocrine TNF and ROS production. Blood 2012, 119:2368-2375. 
59. Graca-Souza AV, Arruda MA, de Freitas MS, Barja-Fidalgo C, Oliveira PL: Neutrophil activation by heme: implications for inflammatory processes. Blood 2002, 99:4160-4165.

60. Arruda MA, Rossi AG, de Freitas MS, Barja-Fidalgo C, Graca-Souza AV: Heme inhibits human neutrophil apoptosis: involvement of phosphoinositide 3kinase, MAPK, and NF-kappaB. J Immunol 2004, 173:2023-2030.

61. Fernandez PL, Dutra FF, Alves L, Figueiredo RT, Mourao-Sa D, Fortes GB, Bergstrand S, Lonn D, Cevallos RR, Pereira RM, et al.: Heme amplifies the innate immune response to microbial molecules through spleen tyrosine kinase (Syk)-dependent reactive oxygen species generation. J Biol Chem 2010, 285:32844-32851.

62. Dutra FF, Bozza MT: Heme on innate immunity and inflammation. Front Pharmacol 2014, 5:115.

63. Cai Y, Cho GS, Ju C, Wang SL, Ryu JH, Shin CY, Kim HS, Nam KW, Jalin AM, Sun $\mathrm{W}$, et al.: Activated microglia are less vulnerable to hemin toxicity due to nitric oxide-dependent inhibition of JNK and p38 MAPK activation. J Immunol 2011, 187:1314-1321.

64. Laird MD, Wakade C, Alleyne CH, Jr., Dhandapani KM: Hemin-induced necroptosis involves glutathione depletion in mouse astrocytes. Free Radic Biol Med 2008, 45:1103-1114.

65. Piazza M, Damore G, Costa B, Gioannini TL, Weiss JP, Peri F: Hemin and a metabolic derivative coprohemin modulate the TLR4 pathway differently through different molecular targets. Innate Immun 2011, 17:293-301.

66. Chen G, Zhang D, Fuchs TA, Manwani D, Wagner DD, Frenette PS: Heme-induced neutrophil extracellular traps contribute to the pathogenesis of sickle cell disease. Blood 2014, 123:3818-3827. *

*This article reinforces the notion that labile heme induces neutrophil activation, as revealed by the generation of neutrophil extracellular traps. The article also suggests that this is an important compoent in the pathogenesi of sickle cell anemia.

67. Monteiro AP, Pinheiro CS, Luna-Gomes T, Alves LR, Maya-Monteiro CM, Porto BN, Barja-Fidalgo C, Benjamim CF, Peters-Golden M, Bandeira-Melo C, et al.: Leukotriene B4 mediates neutrophil migration induced by heme. J Immunol 2011, 186:6562-6567.

68. Andrade BB, Araujo-Santos T, Luz NF, Khouri R, Bozza MT, Camargo LM, Barral A, Borges VM, Barral-Netto M: Heme impairs prostaglandin E2 and TGF-beta production by human mononuclear cells via $\mathrm{Cu} / \mathrm{Zn}$ superoxide dismutase: insight into the pathogenesis of severe malaria. $J$ Immunol 2010, 185:11961204.

69. Porto BN, Alves LS, Fernandez PL, Dutra TP, Figueiredo RT, Graca-Souza AV, Bozza MT: Heme induces neutrophil migration and reactive oxygen species generation through signaling pathways characteristic of chemotactic receptors. J Biol Chem 2007, 282:24430-24436. 


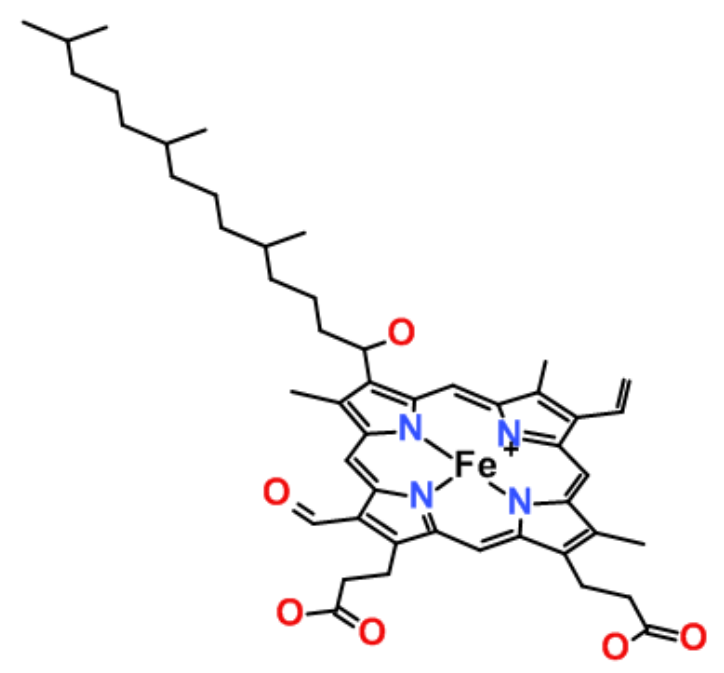

Heme a

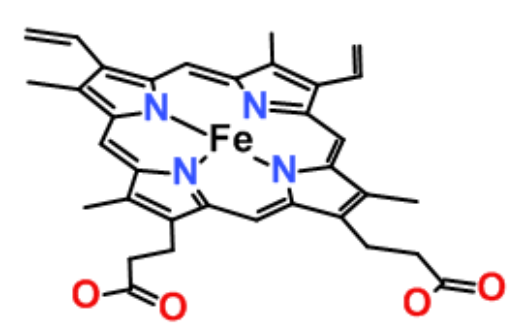

Heme $b$

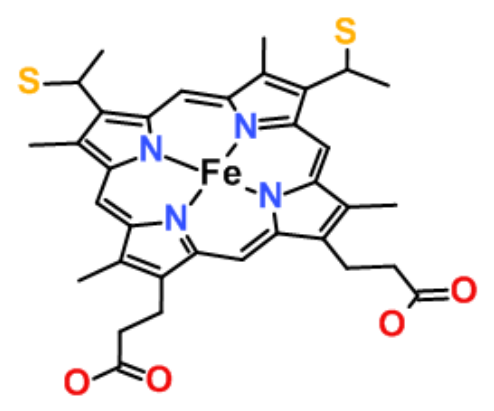

Heme c 


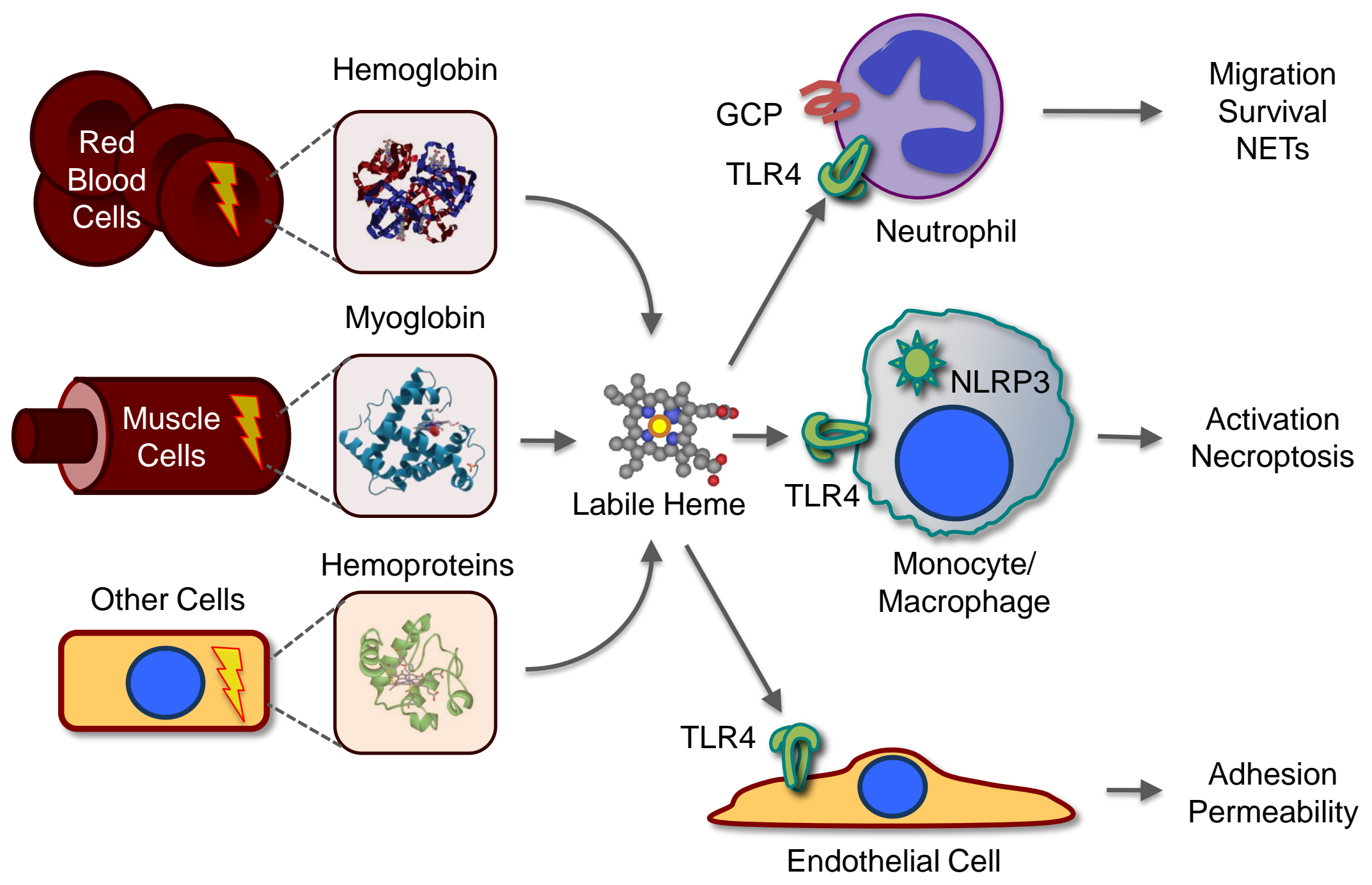

